\title{
Assessment of functional capacity of the elderly associated with the risk for pressure ulcer*
}

\author{
Avaliação da capacidade funcional de idosos associada ao risco de úlcera por pressão
}

Evaluación de la capacidad funcional de ancianos asociada al riesgo de úlcera por presión

\begin{abstract}
Elizabeth Souza Silva de Aguiar ${ }^{1}$, Maria Júlia Guimarães Oliveira Soares ${ }^{2}$, Maria Helena Larcher Caliri ${ }^{3}$, Marta Mirian Lopes Costa ${ }^{4}$, Simone Helena dos Santos Oliveira ${ }^{5}$
\end{abstract}

\begin{abstract}
Objective: To characterize the elderly with physical limitations; to assess functional capacity as it relates to physical mobility, cognitive status and level of functional independence in activities of daily living, and to relate functional capacity to the risk for pressure ulcers. Methods: A quantitative cross-sectional approach, conducted in households in the city of João Pessoa (PB) with seniors who presented physical limitation. Fifty-one elderly were investigated in a two-stage cluster sampling design. Results: There was evidence of impairments in functional capacity of the elderly aged 80 years or more, with more severe physical limitations, cognitive impairment and a higher level of dependency for activities. Significant differences were observed between the level of functional independence in performing activities of daily living and the risk of pressure ulcers. Conclusion: This study allowed for the identification of the elderly in functional decline and at risk for developing pressure ulcers, supporting the implementation of preventive actions at the household level.
\end{abstract}

Keywords: Aged; Pressure ulcer; Risk factors; Disabled persons; People with physical limitations; Physical fitness

\section{RESUMO}

Objetivo: Caracterizar os idosos com limitação física; avaliar a capacidade funcional, conforme a mobilidade física, estado cognitivo e nível de independência funcional para as atividades de vida diária e relacionar a capacidade funcional com o risco para úlcera por pressão. Métodos: Estudo de abordagem quantitativa, transversal realizado em domicílios do Município de João Pessoa-PB com idosos que apresentavam limitação física. Delineamento amostral por conglomerado em dois estágios foram pesquisados 51 idosos. Resultados: Evidenciaram-se comprometimentos na capacidade funcional dos idosos com 80 anos ou mais, como limitação física mais acentuada, déficit cognitivo e maior nível de dependência para as atividades. Diferenças significativas foram observadas entre o nível de independência funcional para a realização de atividades de vida diária e o risco de úlcera por pressão. Conclusão: O estudo possibilitou a identificação de idosos em declínio funcional e em risco para o desenvolvimento de úlceras por pressão, fornecendo subsídios para a implementação de ações preventivas em nível domiciliar.

Descritores: Idoso; Úlcera por pressão; Fatores de risco; Pessoas com deficiência; Aptidão fisical

\section{RESUMEN}

Objetivo: Caracterizar a los ancianos con limitación física; evaluar su capacidad funcional, conforme la movilidad física, estado cognitivo y nivel de independencia funcional para las actividades de la vida diaria y relacionar la capacidad funcional con riesgo para úlcera por presión. Métodos: Estudio de abordaje cuantitativo, transversal realizado en domicilios del Municipio de João Pessoa-PB con ancianos que presentaban limitación física. Fueron investigados 51 ancianos y se usó delineamiento muestral por conglomerado en dos fases. Resultados: Se evidenciaron compromisos en la capacidad funcional de los ancianos con 80 años o más, como limitación física más acentuada, déficit cognitivo y mayor nivel de dependencia para las actividades. Fueron observadas diferencias significativas entre el nivel de independencia funcional para la realización de actividades de la vida diaria y el riesgo de úlcera por presión. Conclusión: El estudio posibilitó la identificación de ancianos en declínio funcional y en riesgo para el desarrollo de úlceras por presión, ofreciendo subsidios para la implementación de acciones preventivas a nivel domiciliario. Descriptores: Acondicionamento físico; Anciano; Úlcera por presión; Factores de riesgo; Personas con discapacidad

\footnotetext{
* Taken from the Master's Thesis entitled "Risk. for pressure ulcer in elderly with functional decline in physical mobility domiciled in João Pessoa - PB," of the Graduate Program in Nursing - Master's Level of the Federal University of Paraiba (Universidade Federal da Paraiba - UFPB) - João Pessoa (PB), Brazil.

${ }^{1}$ Master's degree in Nursing, from the Universidade Federal da Paraíba - UFPB - João Pessoa (PB), Brazil.

${ }^{2}$ Doctorate. Associate Professor, Universidade Federal da Paraíba - UFPB - João Pessoa (PB), Brazil.

${ }^{3}$ Doctorate. Associate Professor, Department of General and Specialized Nursing of the School of Nursing of Ribeirão Preto, University of São Paulo (Universidade do São Paulo- USP) - Ribeirão Preto (SP) Brazil.

${ }^{4}$ Doctorate. Associate Professor at the Universidade Federal da Paraíba - UFPB - João Pessoa (PB), Brazil.

${ }^{5}$ Doctorate. Professor at Technical School of Health, Universidade Federal da Paraíba - UFPB - João Pessoa (PB), Brazil.
} 


\section{INTRODUCTION}

Currently, Brazil and the world are experiencing a period of demographic transition, resulting from the progressive increase of the elderly population. Consequently there is a transformation in the epidemiological profile of the population and an increase in chronic degenerative diseases, with functional limitations that often compromise the autonomy of the elderly person.

Because of the aging process, the demand for care increases based on several physiological changes that occur with biological aging, commonly associated with comorbid conditions. In this process, the progressive decrease in functional capacity is the main alteration encountered, and that can lead to what is called functional disability, that relates to the inability or difficulty of a person to perform basic or more complex physical tasks, necessary for independent living in the community, as well as tasks related to physical mobility ${ }^{(1)}$.

Thus, Souza and Santos ${ }^{(2)}$ add that if the functional capacity is not preserved for activities of daily living (ADL), mobility impairments, sensory perception, sphincter control and deterioration of nutritional status contribute to making the elderly susceptible to complications, such as formation of pressure ulcers (PU), the focus of this study. Thus, early detection of individuals susceptible to this condition becomes essential, especially elderly people with functional decline in physical mobility, in order to avoid loss of skin integrity and / or its complications, as studies have shown high rates of morbidity and mortality in patients with $\mathrm{PU}^{(3,4)}$.

In recent years, several studies have used motor performance, cognitive evaluation and functional independence to assess the functional capacity of the elderly ${ }^{(5-8)}$, however, there are few studies that related age to the development of PU.

Thus, during the conduct of this study, a search was made in the databases of the Virtual Health Library (Biblioteca Virtual de Saúde - BVS) using the Health Sciences Descriptors (Decs / MESH) pressure ulcer and functional capacity, which were repeated in the English and Spanish languages; from these only three articles were selected that addressed the proposed topic. Of these, two articles were international ${ }^{(9,10)}$ and one study was conducted in $\mathrm{Brazil}^{(11)}$.

Therefore, to relate the functional capacity and risk of PU in elderly people emerges as a necessity for assisting the elderly, among innumerable others, since both situations represent a public health problem. Thus, the present study aimed to characterize the profile of the elderly with physical limitations domiciled in the city of João Pessoa; to assess the functional capacity of the elderly, based on physical mobility, cognitive status and level of functional independence in ADL, and to relate functional capacity with the risk of developing PU.

\section{METHODS}

This was a study of a quantitative, cross-sectional design, using a household survey integrated into a larger study, "Living conditions and health of the elderly in Ribeirão Preto-SP and João Pessoa-PB: a comparative study" which assessed the health conditions of the elderly with the age of 60 years or older, living in the urban area of the city of João Pessoa, Paraíba.

Sampling was performed by a two-stage cluster, in the first stage, 20 census tracts were drawn with probability proportional to the number of households, among 617 sectors of the city of João Pessoa-PB, according to the Brazilian Institute of Geography and Statistics (IBGE), in 2007; we then identified the location on the map of the city. Immediately, the streets were listed for each sector and, thereafter, lots were drawn to determine the streets to be visited by interviewers. In the second stage, a fixed number of households were visited, in order to ensure a self-weighting sample, with the street and block drawn for where this search process would be initiated. Therefore, for the sample size calculation the following statistical parameters were adopted: define a sample of 240 individuals, which ensured a maximum error of $6.3 \%$ with $95 \%$ probability, considering a reference population of 61,281 elderly 60 years of age or more, according to the IBGE in 2007. To arrive at the value of $n=240$, the sorting of the 20 census tracts between the existing 617 was designed. Then, 12 seniors were visited within each census tract.

Among the health conditions of the 240 seniors who were part of the household survey, we identified 51 elderly people with physical limitations, which constituted the sample of this study, according to the predetermined inclusion criteria: age 60 years or older, living in urban area of the city, presenting with some physical limitation such as inability to walk or having great or small difficulty in walking, those criteria instituted in the specific instrument. Therefore, not fulfilling any one of these criteria led to the exclusion of the elderly from the $n$-sample.

Before taking part in the study, participants signed the terms of free and informed consent form. Data collection occurred in two simultaneous steps in the months from April to June of 2011: the first was performed by a team of seven researchers, graduate students, trained in the application of the data collection instruments. They used the technique of interviewing the elderly and, when there was cognitive impairment, consulted the responsible person or their caregiver. Within this approach, when identifying elderly with declining physical mobility, depending on the specific instrument, the team of interviewers mailed them to the researcher responsible for the study to return to the home of the research participant. In turn, for the 
second step, we performed a new interview to assess the functional capacity of the elderly and the risk for development of PU, followed by scrutiny of the skin of the research participant to identify PU.

For data collection, we used structured instruments, applied, according to each considered step. In the first interview, we used: an instrument for identifying the elderly, developed by members of the Center for Research in Geriatric and Gerontology Nursing (NUPEGG) at the School of Nursing of Ribeirão Preto (EERP); the Mini Mental State Examination (MMSE) developed by Folstein et al. ${ }^{(12)}$, chosing the translation and adaptation of Bertolucci et al. ${ }^{(13)}$; and the Instrument for identification and referral of older adults with some physical limitation, developed by the researchers of this study. In the second interview, the Katz Scale ${ }^{(14)}$, adapted and validated in Brazil by Lino et $\mathrm{al}^{(15)}$, the Braden Scale ${ }^{(16)}$, translated and validated in Brazil by Paranhos and Santos ${ }^{(17)}$, and an Assessment Instrument of the Person with PU, prepared by the authors of this study, were utilized.

Data were double entered and validated in a spreadsheet in the Microsoft Excel program, and statistical calculations were performed with the SPSS (Statistical Package for the Social Sciences), software, version 15. To analyze the data, we obtained absolute distribution, univariate and bivariate percentages and statistical measures: mean, median and standard deviation (descriptive statistic techniques), and also inferential statistical techniques by using the chi-square test or the Fisher's exact test, when there were no conditions for use of the prior. It is highlighted that the significance level used in the statistical tests was $5 \%$ and the intervals were obtained with $95 \%$ confidence.

This research project was approved by the Ethics Committee on Research of the Centre of Health Sciences, Universidade Federal da Paraíba, protocol n. ${ }^{\circ}$ 0124/11.

\section{RESULTS}

The majority of participants were female $(56.9 \%)$, with a mean age of 80.51 years (median 81.00 years, standard deviation of 9.06 years, and coefficient of variation of $11.25 \%) ; 54.9 \%$. The self-referred skin color of the elderly was "not white"; $41.1 \%$ were widowed, and $70.6 \%$ were of the Catholic religion. Thirty respondents $(58.8 \%)$ knew how to read and write.

With regard to individual income, $62.7 \%$ earned a minimum wage, with $90.2 \%$ coming from retirement; as family income, variations were registered: $5.9 \%$ with household income less than or equal to a minimum wage; $41.1 \%$ with more than three times the minimum wage; and $27.5 \%$ higher than three times minimum wage; however, $25.5 \%$ did not report the income. It was also found that a significant number $(86.3 \%)$ had a caregiver at home, represented by family members such as spouses and children.

Regarding the clinical conditions of the elderly, the data in Table 1 presents the health problems or underlying disease, with higher frequencies for: arterial hypertension (51\%), impaired hearing or vision (43.1\%), and urinary or fecal incontinence (43.1\%).

Table 1. Evaluation of health problems presented by the elderly based on age range. João Pessoa, 2011.

\begin{tabular}{|c|c|c|c|c|}
\hline \multirow[b]{2}{*}{ VARIABLES } & \multicolumn{4}{|c|}{ Age group } \\
\hline & $\begin{array}{c}60 \text { to } 79 \text { years } \\
n(\%)\end{array}$ & $\begin{array}{c}80 \text { years or more } \\
n(\%)\end{array}$ & $\begin{array}{c}\text { Total group } \\
\mathbf{n}(\%)\end{array}$ & p-value \\
\hline \multicolumn{5}{|l|}{ Health Problems (1) } \\
\hline Arterial hypertension & $12(50.0)$ & $14(51.9)$ & $26(51.0)$ & $\mathrm{p}(2)=0.895$ \\
\hline Impaired Hearing & $9(37.5)$ & $13(48.1)$ & $22(43.1)$ & $\mathrm{p}(2)=0.443$ \\
\hline Urinary or fecal incontinence & $8(33.3)$ & $14(51.9)$ & $22(43.1)$ & $\mathrm{p}(2)=0.183$ \\
\hline Impaired Vision & $9(37.5)$ & $13(48.1)$ & $22(43.1)$ & $\mathrm{p}(2)=0.443$ \\
\hline $\begin{array}{l}\text { Neurological disease (Parkinson's / Alzheimer's / } \\
\text { sclerosis) }\end{array}$ & $6(25.0)$ & 15(55.6) & $21(41.2)$ & $\mathrm{p}(2)=0.027^{*}$ \\
\hline Arthritis (rheumatoid / osteoarthritis) & $8(33.3)$ & $11(40.7)$ & $19(37.3)$ & $\mathrm{p}(2)=0.585$ \\
\hline Intestinal constipation & $8(33.3)$ & 11(40.7) & $19(37.3)$ & $\mathrm{p}(2)=0.585$ \\
\hline Cerebral vascular accident & $8(33.3)$ & $7(25.9)$ & $15(29.4)$ & $\mathrm{p}(2)=0.562$ \\
\hline Spinal problems & $6(25.0)$ & $8(29.6)$ & $14(27.5)$ & $\mathrm{p}(2)=0.712$ \\
\hline Diabetes mellitus & $9(37.5)$ & $4(14.8)$ & $13(25.5)$ & $\mathrm{p}(2)=0.064$ \\
\hline Anxiety & $8(33.3)$ & $3(11.1)$ & 11(21.6) & $\mathrm{p}(2)=0.054$ \\
\hline Heart disease & $3(12.5)$ & $7(25.9)$ & $10(19.6)$ & $\mathrm{p}(3)=0.300$ \\
\hline Gastrointestinal disease high & $3(12.5)$ & $7(25.9)$ & $10(19.6)$ & $\mathrm{p}(3)=0.300$ \\
\hline
\end{tabular}

$\left(^{*}\right)$ : Difference significant at $5.0 \%$ level.

(1): Whereas a single elderly person has more than one health problem, register the basis for the calculation of the percentages and not the total.

(2): By the Pearson's chi-square test.

(3): By the Fisher exact test. 
According to Table 1, neurological disease achieved a higher frequency in the elderly aged 80 years or more $(55.6 \%)$. Moreover, diabetes mellitus (DM) and anxiety were greater between 60 and 79 years, but the differences were not statistically significant. Only neurological disease presented significant associations with age range $(\mathrm{p}<0.05)$.

The types of medications being used included: antihypertensives (43.1\%), psychotropics (29.4\%), hypoglycemics $(21.6 \%)$, neuroleptics $(19.6 \%)$, and other medications to a lesser extent, such as cerebral and / or peripheral vasoactives, followed by supplements of vitamins / minerals / amino acids, antiplatelet agents, insulin, antacids, anti-inflammatories, and others.

Therefore, with regard to decline of functional capacity, those elderly 80 years or older accounted for the group with the largest compromise, according to the variables of physical limitations, cognitive status and functional independence in ADLs. As for physical limitations, $33.3 \%$ had great difficulty in walking, and $56.9 \%$ could not ambulate.

Considering the functional capacity as measured by the Katz scale ${ }^{(15)}, 54.9 \%$ of the elderly were totally dependent for ADL. Regarding the cognitive state, according to the MMSE, we observed a significant association $(p<0.05)$ with increasing age, where the number of elderly people with cognitive impairment was higher among those aged 80 more $(85.2 \%)$.

The results of the bivariate analysis of the associations between physical limitation and the Katz index, as well as the relationship between cognitive status and Katz index are presented in the data in Table 2. It was found that, for the first association, the percentage of elderly who were dependent in five to six tasks was higher ( $p<0.005)$ among those who were unable to ambulate $(70.6 \%)$. As for the cognitive state and the Katz index, of the 34 elderly who were dependent in five to six tasks, the majority, $29(85.3 \%)$ presented cognitive deficit.

It was also possible to identify a relationship between the level of functional dependence of the elderly and the presence of the caregiver. Those people who were dependent for three to six tasks corresponded to the majority among the elderly who had caregivers $(88.6 \%)$, compared with those who had no caregiver (14.3\%).

For the assessment of PU risk among the elderly, based on the Braden Scale, according to age range, $49 \%$ of seniors were identified with some level of risk for PU (Table 3).

Table 2. Evaluation of physical limitations and cognitive status according to the Katz Index. João Pessoa, 2011.

\begin{tabular}{|c|c|c|c|c|c|c|}
\hline \multirow[b]{2}{*}{ Variables } & \multicolumn{4}{|c|}{ Katz index ${ }^{(1)}$} & \multirow[b]{2}{*}{$\begin{array}{c}\text { Total group } \\
\mathbf{n}(\%)\end{array}$} & \multirow[b]{2}{*}{$\mathrm{p}$-value } \\
\hline & $\begin{array}{c}0 \\
\mathrm{n}(\%) \\
\end{array}$ & $\begin{array}{l}1-2 \\
\mathrm{n}(\%)\end{array}$ & $\begin{array}{l}3-4 \\
\mathrm{n}(\%)\end{array}$ & $\begin{array}{l}5-6 \\
\mathrm{n}(\%)\end{array}$ & & \\
\hline TOTAL & $2(100.0)$ & $9(100.0)$ & $6(100.0)$ & $34(100.0)$ & $51(100.0)$ & \\
\hline \multicolumn{7}{|l|}{ Physical limitation } \\
\hline Little difficulty in walking & $1(50.0)$ & 1(11.1) & - & $3(8.8)$ & $5(9.8)$ & $\mathrm{p}^{(2)}=0.013^{*}$ \\
\hline Great difficulty in walking & - & $6(66.7)$ & 4(66.7) & $7(20.6)$ & $17(33.3)$ & \\
\hline Can not walk & $1(50.0)$ & $2(22.2)$ & $2(33.3)$ & $24(70.6)$ & $29(56.9)$ & \\
\hline \multicolumn{7}{|l|}{ Cognitive state } \\
\hline With deficit & - & $4(44.4)$ & $1(16.7)$ & $29(85.3)$ & $34(66.7)$ & $\mathrm{p}^{(2)}<0.001^{*}$ \\
\hline Without deficit & $2(100.0)$ & $5(55.6)$ & $5(83.3)$ & $5(14.7)$ & $17(33.3)$ & \\
\hline
\end{tabular}

(*): Significant difference at $5.0 \%$ level.

(1): Katz index: 0 = Independence; 1-2 = Dependent on 1-2 tasks; 3-4 = Dependent on 3-4 tasks; 5-6 = Dependent on 5-6 tasks.

(2): By the Fisher exact test.

Table 3. Distribution of the frequencies of the Braden Scale, according to age range. João Pessoa, 2011.

\begin{tabular}{lcccc}
\hline \multicolumn{1}{c}{ Variable } & \multicolumn{2}{c}{ Age range } & & \\
& $\mathbf{6 0 - 7 9}$ years & $\mathbf{8 0}$ years or more & Total group & $\mathbf{p}$-value \\
& $\mathbf{n}(\mathbf{\%})$ & $\mathbf{n}(\mathbf{\%})$ & $21(100.0)$ \\
\hline TOTAL & $24(100.0)$ & $27(100.0)$ & & \\
Risk scores for PU & & & & \\
Moderate risk / High risk (13-14; 10-12) & - & $2(7.4)$ & $2(3.9)$ & $\mathrm{p}^{(1)}=0.170$ \\
With risk (15 a 18) & $9(37.5)$ & $14(51.9)$ & $23(45.1)$ & \\
Without risk $(>=19)$ & $15(62.5)$ & $11(40.7)$ & $26(51.0)$ & \\
\hline
\end{tabular}

(1): Using the Fisher exact test.

(2): Using the Pearson chi-square test.

It was possible to visualize percentage differences in both age groups, considering that the majority of the elderly classified at some level of risk refers to people aged 80 years or more $(16 ; 59.3 \%)$. 
The findings made it possible to employ the Fisher exact test for associations between the risk scores for PU and the variables: physical limitation, the MMSE cognitive status and functional independence by the Katz Scale, with statistical significance at $\mathrm{p}<0.05$.

We identified four elderly with PU, a prevalence of $7.8 \%$, and by means of statistical analysis, verified that there was an association between higher functional dependence for ADL and the presence of a PU.

\section{DISCUSSION}

As to the profile of the respondents, most were called "older elderly" (80 or older), a fact explained by the higher occurrence with advancing age of physical limitations, therefore, inclusion criteria of the study. Other demographic data presented were corroborated by results obtained from national studies ${ }^{(18-20)}$. The presence of the caregiver in the home was justified by the dependency for care they presented, also identified by Amendola et $\mathrm{al}^{(21)}$.

With regard to clinical conditions, $80.4 \%$ reported having four or more comorbidities. Thus, based on these findings, we infer that such health conditions contribute to functional decline in physical mobility and functional dependence for the performance of ADL, in the population studied, also confirmed in a study by Alves et al. ${ }^{(22)}$, in which the influence of chronic diseases on the functional dependence of elderly residents in the city of São Paulo was evident.

Concerning the assessment of functional capacity, the data in Table 2 show high compromise in functional capacity of the elderly with 80 years or more, with more pronounced physical limitations, cognitive deficits and higher level of dependency for ADL, which was also found in previous research ${ }^{(18-19,23)}$.

The bivariate analyses in Table 2 confirm directly proportional associations between functional decline in physical mobility (physical limitation) and greater dependence for ADL among the elderly, equally, those with compromised cognitive performance presenting with more dependence. In the latter correlation, it was observed that there were some elderly people without cognitive impairment, who already had some level of dependency for ADLs. Such correlations converge with several national studies ${ }^{(18-19,24-25)}$.

An international study showed that, when an individual ages, some organic systems experience a decline in function, and it is commonly associated with the aging process. But, while these changes have little influence on daily needs of most elderly, health problems that occur in sensory, neurological and musculoskeletal systems may place some individuals at risk of developing some functional restrictions ${ }^{(26)}$.
It was possible to ascertain that almost half (49\%) of the elderly were classified at some level of risk for PU, based on the Braden Scale. However, it is worth pointing out that people who are not classified as at risk should be monitored for the presence of other factors, intrinsic or extrinsic, since the very old age and clinical conditions, observed in this and other studies ${ }^{(27,28)}$, denounce the vulnerability of these people for loss of skin integrity.

There were also statistically significant differences between the risk scores for PU on the Braden Scale and the variables of physical limitations, cognitive status and level of functional independence in ADLs. Some categories of these variables coincided with some subscales of the Braden Scale, strengthening the correlation. Therefore, it was found that the larger the impairment of physical mobility, the greater the number of elderly persons found at risk on the Braden scale for skin ulcer formation, a consensual condition that is described in studies ${ }^{(29,30)}$. In the same direction there are cognitive losses, generally determined by senility and underlying diseases, such as cardiovascular, neurological and degenerative diseases involving various factors, from the inability for self-care, to sensory loss and physical immobility that together predispose a person to PU risk ${ }^{(29)}$. Therefore, the presence of cognitive deficit and the classification of risk for PU on the Braden Scale are correlated.

When evaluating the level of functional independence in ADLs and the risk for PU, the associations were significant, demonstrating that the increased dependence for performing ADLs is directly related to the decrease in the score of the Braden Scale, since the higher the dependence levels for the implementation of activities, as found in the study, the greater the risk for PU, a result also confirmed by Lisbon ${ }^{(28)}$ and Faustino ${ }^{(31)}$. Likewise, in the current and other national and international studies ${ }^{(10-11,28,32)}$, the large functional dependence for ADL contributed to the presence of PU.

In this study, it is considered that the object investigated could be better portrayed with a larger sample and with the inclusion of variables, such as nutritional status. However, due to the scarcity of studies on function and PU, this research could awaken in the health professionals, especially nurses, and also in the health system as a whole, a specific look at the risk of PU, that occurs mainly in the elderly with impaired functional capacity needing permanent assistance in their homes.

\section{CONCLUSION}

The majority of those surveyed were called "the older elderly" (80 or older), with cognitive deficits and high levels of dependency for activities of daily living, which allowed us to observe, along with declining 
physical mobility, that they had compromised functional capacity, and in turn, the more adversely affected, the greater was the risk of developing PU in the elderly. Thus, early detection of individuals with indicators of functional disability and risk for PU contributes substantially to the planning of preventive actions in the home environment, improves quality of life, reduces morbidity and even mortality in this population.

\section{REFERENCES}

1. Rosa TE, Benício MH, Latorre MR, Ramos LR. [Determinant factors of functional status among the elderly]. Rev Saúde Pública. 2003; 37(1):40-8. Portuguese.

2. Souza DM, Santos VL. Úlceras por pressão e envelhecimento. Rev Estima. 2006;4(1):36-44.

3. Fernandes LM, Caliri MH, Haas VJ. The effect of educative interventions on the pressure ulcer prevention knowledge of nursing professionals. Acta Paul Enferm. 2008; 21(2):305-11.

4. Fernandes LM, Caliri MH. Using the braden and glasgow scales to predict pressure ulcer risk in patients hospitalized at intensive care units. Rev Latinoam Enferm. 2008; 16(6):973-8.

5. Costa EC, Nakatani AY, Bachion MM. [Elder's community capacity to develop Daily Life Activities and Daily Instrumental Life Activities]. Acta Paul Enferm. 2006;19 (1 Suppl 1):43-35. Portuguese.

6. Parahyba MI, Veras R. [Socio-demographic differentials in the functional decline among the elderly in Brazill. Ciênc Saúde Coletiva. 2008;13 (4):1257-64. Portuguese.

7. Minosso JS, Amendola F, Alvarenga MR, Oliveira MA. Validation of the Barthel Index in elderly patients attended in outpatient clinics, in Brazil. Acta Paul Enferm. 2010; 23(2):218-23.

8. Ferreira PC, Tavares DM, Rodrigues RA. Sociodemographic characteristics, functional status and morbidity among older adults with and without cognitive decline. Acta Paul Enferm. 2011; 24(1):29-35.

9. Gamarra Samaniego P. [Consequences of the hospitalization in the old one]. Rev Soc Peru Med Interna. 2001;14(2):90-8. Spanish.

10. Damián J, Valderrama-Gama E, Rodríguez-Artalejo F, Martín-Moreno JM. [Health and functional status among elderly individuals living in nursing homes in Madrid]. Gac Sanit. 2004;18(4):268-74. Spanish.

11. Rabeh SA, Caliri MH, Haas VJ. [Prevalence of pressure ulcer in individuals whith post-trauma functional capacity]. Acta Fisiatr. 2009;16(4):173-8. Portuguese.

12. Folstein MF, Folstein SE, McHugh PR. "Mini-mental state". A practical method for grading the cognitive state of patients for the clinician. J Psychiatr Res. 1975;12(3):189-98.

13. Bertolucci PF, Brucki SM, Campaccii SR, Juliano Y. [The Mini-Mental State Examination in a general population: impact of educational status]. Arq Neuropsiquiatr. 1994;52(1):1-7. Portuguese.

14. Katz S, Ford AB, Moskowitz RW, Jackson BA, Jaffe MW. Studies of illness in the aged. The index of ADL: a standardized measure of biological and psychosocial function. JAMA. 1963;185(12):914-9.

15. Lino VT, Pereira SR, Camacho LA, Ribeiro Filho ST, Buksman S. [Cross-cultural adaptation of the Independence

\section{ACKNOWLEDGEMENTS}

To the Coordination of Improvement of Higher Education Personnel (Coordenação de Aperfeiçoamento de Pessoal de Nível Superior - CAPES) for major research funding: Living conditions and health of the elderly in Ribeirão Preto-SP and João Pessoa-PB: a comparative study.

in Activities of Daily Living Index (Katz Index)]. Cad Saúde Pública. 2008;24(1):103-12. Portuguese.

16. Braden B, Bergstrom N. A conceptual schema for the study of the etiology of pressure sores. Rehab Nurs. 1987;12(1): 8-12.

17. Paranhos WY, Santos VL. Avaliação do risco de úlcera de pressão por meio da escala de Braden na língua Portuguesa. Rev Esc Enf USP. 1999; 33(No Espec): 191-206.

18. Maciel AC, Guerra RO. Influência dos fatores biopsicossociais sobre a capacidade funcional de idosos residentes no nordeste do Brasil. Rev Bras Epidemiol. 2007;10(2):178-89.

19. Giacomin KC, Peixoto SV, Uchoa E, Lima-Costa MF. [A population-based study on factors associated with functional disability among older adults in the Great Metropolitan Belo Horizonte, Minas Gerais State, Brazill. Cad Saúde Pública. 2008; 24(6):1260-70. Portuguese.

20. Pedrazzi EC, Della Motta T'T, Vendrúscolo TR, FabrícioWehbe SC, Cruz IR, Rodrigues RA. Household arrangements of the elder elderly. Rev Latinoam Enferm. 2010;18(1):18-25.

21. Amendola F, Oliveira MA, Alvarenga MR. [Quality of life of family caregivers of patients dependent on the family health program]. Texto \& Contexto Enferm. 2008;17(2):266-72. Portuguese.

22. Alves LC, Leimann BC, Vasconcelos ME, Carvalho MS, Vasconcelos AG, Fonseca TC, et al. [The effect of chronic diseases on functional status of the elderly living in the city of São Paulo, Brazil]. Cad Saúde Pública. 2007;23(8):1924930. Portuguese.

23. Alves LC, Leite IC, Machado CJ. Factors associated with functional disability of elderly in Brazil: a multilevel analysis. Rev Saúde Pública. 2010;44(3):2-11.

24. Suh GH, Ju YS, Yeon BK, Shah A. A longitudinal study of Alzheimer's disease: rates of cognitive and functional decline. Int J Geriatr Psychiatry. 2004;19(9):817-24.

25. Talmelli LF, Gratão AC, Kusumota L, Rodrigues RA. Functional independence level and cognitive deficit in elderly Individuals with Alzheimer's disease]. Rev Esc Enferm USP. 2010;44(4):933-9. Portuguese.

26. Steffen TM, Hacker TA, Mollinger L. Age-and gender -related test performance in community-dwelling elderly people: Six Minute Walk Test, Berg Balance Scale, Timed Up \& Go Test, and gait speeds. Phys Ther. 2002;82(2):128-37.

27. Souza DM. Incidência de úlceras por pressão e fatores de risco em idosos institucionalizados [dissertação]. São Paulo: Universidade de São Paulo, Escola de Enfermagem; 2005.

28. Lisboa CR. Risco para úlcera por pressão em idosos institucionalizados [dissertação]. Belo Horizonte: Universidade Federal de Minas Gerais, Escola de Enfermagem; 2010.

29. Dealey C. Cuidando de feridas: um guia para as enfermeiras. 
Lacerda RA, Santos VL, tradutores. 3a ed. São Paulo: Atheneu; 2008. Tratamento de pacientes com feridas crônicas; p.121-68.

30. European Pressure Ulcer Advisory Panel, National Pressure Ulcer Advisory Panel. Prevention and treatment of pressure ulcers: quick reference guide [Internet]. Washington DC: National Pressure Ulcer Advisory Panel; 2009 [cited 2011 Jan 10]. Available from: http://www.npuap.org/wp-content/uploads/2012/02/ Final_Quick_Prevention_for_web_2010.pdf
31. Faustino AM. Úlcera por pressão e fatores de risco em pacientes hospitalizados com fratura de quadril e de fêmur [dissertação]. Ribeirão Preto: Universidade de São Paulo, Escola de Enfermagem de Ribeirão Preto; 2008.

32. Ng YS, Jung H, Tay SS, Bok CW, Chiong Y, Lim PA. Results from a prospective acute inpatient rehabilitation database: clinical characteristics and functional outcomes using the Functional Independence Measure. Ann Acad Med Singapore. 2007;36(1):3-10. 